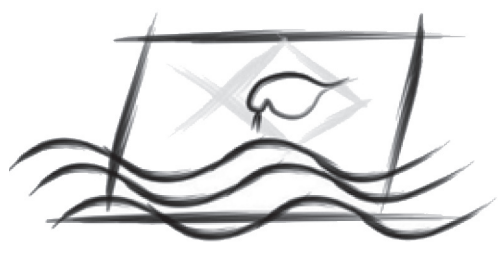

J. Braz. Soc. Ecotoxicol., v. 6, n. 1, 2011, 9-13

doi: $10.5132 /$ jbse.2011.01.002

ECOTOX - Brazil

\title{
Evaluation of the Acute Effects of Organic Solvents on Adults of Sitophilus zeamais Motschulsky, 1855 (Coleoptera, Curculionidae)
}

\author{
T. A. de Oliveira ${ }^{1 *}$, B. Ronchi-Teles ${ }^{1}$, R. B. de Oliveira ${ }^{1}$, C. R. V. da Fonseca ${ }^{1}$, \\ S. L. R. Da Silva' 2 P. A. dos Santos ${ }^{3} \&$ C. V. Nunez \\ ${ }^{1}$ Coordenação de Pesquisas em Entomologia, Instituto Nacional de Pesquisas da Amazônia, \\ Av. André Araújo, 2936, Aleixo, CEP 69060-001, Manaus - AM, Brasil \\ ${ }^{2}$ Instituto de Ciências Biológicas, Universidade Federal do Amazonas - UFAM, Manaus - AM, Brasil \\ ${ }^{3}$ Coordenação de Pesquisas em Produtos Naturais, Instituto Nacional de Pesquisas da Amazônia, \\ Av. André Araújo, 2936, Aleixo, CEP 69060-001, Manaus - AM, Brasil
}

(Received April 14, 2010; Accepted November 16, 2010)

\begin{abstract}
The continuous use of synthetic insecticides has created problems for the environment and human health. With the objective of reducing such problems, ecofriendly measures have been taken and, in this case, plants have representing an important resource for pest control. Due to the increase of studies using organic extracts in bioassays and the difficulty of finding solubilizant agents that do not interfere in the results, the aim of this work was to evaluated the acute effect of different solvents on Sitophilus zeamais by contact and ingestion assays. The results suggest that pure dimethyl sulphoxide (DMSO) and Tween20 solvents have toxic acute effects on adults of S. zeamais, but they can be used diluted at 1 or $5 \%$ with no toxic acute effect. On contrary, pure dichloromethane (DCM) and methanol $(\mathrm{MeOH})$ did not cause any acute effect on target organism. Thus, DCM and MeOH solvents even in the pure form and the Tween-20 and DMSO diluted at 1 or $5 \%$ can be used as solubilizant agents for apolar to medium polarity plant extracts, involving contact or ingestion assay on adults of S. zeamais.
\end{abstract}

Keywords: plant extracts, stored grain pest, solvents, toxicity.

\section{RESUMO}

\section{Avaliação do Efeito Agudo de Solventes Orgânicos Sobre Adultos de Sitophilus zeamais Motschulsky, 1855 (Coleoptera: Curculionidae)}

O uso contínuo de inseticidas sintéticos tem criado problemas para a saúde humana e para o meio ambiente. Com o objetivo de diminuir estes problemas, medidas sustentáveis têm sido adotadas, e neste caso, espécies vegetais têm representado um importante recurso para o controle de pragas. Devido ao aumento de estudos usando extratos orgânicos e a dificuldade de encontrar agentes solubilizantes que não interfiram nos resultados, este trabalho propôs avaliar o efeito agudo de diferentes solventes sobre Sitophilus zeamais pelas vias contato e ingestão. Os resultados sugerem que os solventes dimetil sulfóxido (DMSO) e Tween-20 (ambos puro) causam efeito tóxico agudo em adultos de $S$. zeamais, mas os mesmos podem ser usados diluídos a 1 ou $5 \%$ sem causar efeito tóxico agudo. No entanto, os outros solventes testados diclorometano (DCM) e metanol $(\mathrm{MeOH})$, ambos puro, não causaram efeito agudo no organismo alvo, por contato e ingestão. Assim, os solventes DCM e $\mathrm{MeOH}$ ambos na forma pura e o Tween-20 e o DMSO, diluídos a 1 ou 5\% podem ser usados como solubilizantes para extratos de baixa e média polaridade, em ensaios de contato e ingestão contra adultos de S. zeamais.

Palavras-chave: extratos vegetais, pragas de grãos armazenados, solventes, toxicidade.

\footnotetext{
* Corresponding author: Taciane Almeida de Oliveira, e-mail: taciane.ao@gmail.com.br.
} 


\section{INTRODUCTION}

The maize weevil Sitophilus zeamais Motschulsky, 1855 (Coleoptera: Curculionidae) has been found mainly in corn grains and their sub-products. It is an important stored maize pest; however, it can be hosted on a high number of grains. $S$. zeamais is also capable to attack grains in the field phase. In Brazil, it has been considered one of the major maize stored pest, specially for the capacity of easily penetrate in the grain mass, high biotic potential, crossed infestation and for the fact that all insect phases are potential damage cause (Gallo et al., 2002; Lazzari \& Lazzari, 2009).

The principal stored grain pest control method still used today is based on successive applications of synthetic insecticides (Coitinho et al., 2006; Souza \& Trovão, 2009). In this case, liquefied fumigants are used (Gallo et al., 2002; Lee et al., 2004; Coitinho et al., 2006; Souza \& Trovão, 2009). These products have been successful, but, the indiscriminate and continuous use has been creating serious problems for the environment and the human beings health (Jacobson, 1982; Tapondjou et al., 2002; Poletti \& Omoto, 2003; Viegas Júnior, 2003).

With the objective of decreasing the damages caused by pesticides it is more desirable the adoption of sustainable and effective measures in the pest's control. With this philosophy, the number of studies involving the search for molecules less poisonous capable to act on certain population, taking into account time of degradation, specific target, action over beneficial insects, ecosystems and the human being health is increasing (Saito \& Lucchini, 1998; Fazolin et al., 2002; Lee et al., 2004; Estrela et al., 2006).

For this, the use of plants as insecticide source is an important resource with the objective of reducing stored product pest populations (Liu \& Ho, 1999; Amaral et al., 2006), and so, several botanical families have been studied (Oliveira \& Vendramim, 1999; Almeida et al., 2004; Papachristos \& Stamopoulos, 2004; Paul et al., 2009). In Brazil, the control of adult's S. zeamais through plant extractive or other substances of vegetable origin has been verified in some works (Procópio et al., 2003; Tavares \& Vendramim, 2005; Estrela et al., 2006; Fazolin et al., 2007; Coitinho et al., 2006; Souza \& Trovão, 2009).

In bioassays that evaluate insecticide, fungicide and bactericide properties, solvents have been used in the solubilization of compounds with low polarity (Mahasneh \& El-Oqlah, 1999; Gonçalves-Gervásio \& Vendramim, 2004; Inoue et al., 2005; Kukić et al., 2008). These compounds are still used as herbicide adjuvants or in the preparation of products that present inhibitory effect on the plant species development (Stahlman et al., 1997). However, when organic extracts are used in toxicological assays, it's important to take into account the solvent toxicities used as extract solubilizants on the organism-target (Hammer et al., 1999; Nascimento et al., 2008), because it is known that solvents can interact with the organisms target causing the death of the same ones, or interfering on the result. Chagas et al. (2002) observed that essential oils when transformed in emulsified oils had their activity potentiated when tested on larvae ticks. Nascimento et al. (2008) observed that the emulsifier Tween-80 when added to the long pepper essential oil showed fungitoxic influence Alternaria alternate mycelia grown of (Fr.) Keissl. (1912) (Fungi: Hyphomycetes).

This research evaluated the acute effect of dimethyl sulphoxide, Tween-20, dichloromethane and methanol solvents on adults of $S$. zeamais by contact or ingestion assay, with the intention to eliminate any effect of these solvents used as solubilizants in future assays.

\section{MATERIALS AND METHODS}

The tests were accomplished at the Laboratory of Agricultural Entomology of the Amazonia National Research Institute (INPA), in Manaus, Amazon - Brazil. All S. zeamais specimens used in the experiments were from stocks cultures creation. All bioassays were made at $25 \pm 2{ }^{\circ} \mathrm{C}$ temperature, $60 \pm 10 \%$ relative humidity (r.h.) and 12:12 light:dark photoperiod conditions.

Four solvents were selected for the assay: dimethyl sulphoxide (DMSO) (pure, 1 and 5\%), polysorbate surfactant (Tween-20) (pure, 1 and 5\%), dichloromethane (DCM) and methanol $(\mathrm{MeOH})$, both pure, through two administration ways: contact and ingestion. For each solvent concentration were performed two treatments: control group (without any chemical substance) and treatment group (with the respective solvent). Both assays (contact and ingestion) were full randomized with five repetitions, each one with 20 non-sexed adults between 10 and 20 days of age, totalizing 100 individuals for treatment.

\section{Contact bioassay}

The contact mortality assay was performed by using filter paper as proposed by Tavares \& Vendramim, (2005). Filter papers $(9.0 \mathrm{~cm}$ diameter) were impregnated with $1 \mathrm{~mL}$ aliquots of each solvent (treatment group), and the control group didn't received anything. The filters were air dried for 1 hour. Then, each paper was put into a Petri dish, and adults of $S$. zeamais were confined on it, taking the care of sealing each with a plastic film, to prevent the insects escape. The number of death individuals was count after 5 days and the specimens were considered dead with a complete absence of movement.

\section{Ingestion bioassay}

The ingestion assay was installed based on the work accomplished by Llanos et al. (2008) with minor modifications, using $20 \mathrm{~g}$ of mixed corn, type 2 . Before the tests, the grains were maintained for about 2 months in freezers for expunge. Each treatment was performed impregnating the corn grains with $2 \mathrm{~mL}$ of each solvent and the control group without; the corn mass was homogenized and dried for 1 hour. The number of dead individuals in control and treatment were counted 15 days after the adult's confinement. The individuals were considered dead with total absence of movement.

\section{Statistic analyze}

Student's t-Test method was applied to all solvents at first, and for each concentration (MeOH and DCM, both pure, and for DMSO and Tween-20 pure, 1 and 5\%) and analyzed 
separately. After, ANOVA one three-way variance analyses was performed for DMSO and Tween-20 solvents, concentrations and administration way. A critical value of $(p<0.05)$ was selected as evidence of a difference significant. In this case, Tukey test was used as a post hoc test to determine which variable different significantly and the statistical analysis was performed by Statistica for Windows (StatSoft, 1997).

\section{RESULTS}

The first analysis suggest that only the solvents DMSO and Tween-20, both pure, are capable to cause a toxic acute effect on the adults of $S$. zeamais, by ingestion assay and DMSO by contact assay (Table 1 and 2). Dichloromethane (DCM) and methanol (MeOH), both pure, and with DMSO and Tween-20 diluted both at 1 and $5 \%$ were no toxic, because there was no observed significantly difference between treated and control group, on the two administration ways.

Analyzing the dead individuals percentage it was possible to observe that DMSO pure killed $100 \%$ of them, as for contact or ingestion, while Tween- 20 pure killed $38 \%$ by contact and the total mortality was observed on the ingestion assay (Table 3).

Table 1 - Results of pure dimethyl sulphoxide (DMSO) assayed on Sitophilus zeamais individuals by contact and ingestion.

\begin{tabular}{clrccc}
\hline $\begin{array}{c}\text { Administration } \\
\text { way }\end{array}$ & Treatment & Means & d.f. & t-value & $p$ \\
\hline Contact & Control & 0.60 & 8 & 60.7157 & $0.000000^{*}$ \\
& DMSO (pure) & 19.80 & & & \\
Ingestion & Control & 2.20 & $4^{* *}$ & 14.4671 & $0.000133^{*}$ \\
& DMSO (pure) & 19.80 & & & \\
\hline
\end{tabular}

*Significant differences $(p<0.05)$ found applying the Student's t-Test method; **Degrees of freedom adjusted to perform the inferential method. Original significance level: $p$-value $=0.000001($ d.f $=8)$.

Table 2 - Results of pure polysorbate surfactant (Tween-20) assayed on Sitophilus zeamais individuals by contact and ingestion.

\begin{tabular}{clrccc}
\hline $\begin{array}{c}\text { Administration } \\
\text { way }\end{array}$ & Treatment & Means & d.f. & t-value & $p$ \\
\hline Contact & Control & 0.20 & $4^{*}$ & 3.6108 & $0.022540^{* *}$ \\
& Tween-20 & 7.60 & & & \\
Ingestion & Control & 3.40 & $4^{*}$ & 23.1931 & $0.000020^{* *}$ \\
& Tween-20 & 19.80 & & & \\
\hline
\end{tabular}

*Degrees of freedom adjusted to perform the inferential method. Original significance level: $p$-value $=0.000001(\mathrm{~d} . \mathrm{f}=8) ; * *$ Significative differences $(p<0.05)$ found applying the Student's t-Test method.

Table 3 - Percentage of Sitophilus zeamais individuals dead by contact and ingestion assay, considering each solvent and their respective control.

\begin{tabular}{lrrrrr}
\hline \multirow{2}{*}{ Solvent used } & \multicolumn{2}{c}{ Contact assay } & & \multicolumn{2}{c}{ Ingestion assay } \\
\cline { 2 - 3 } \cline { 5 - 6 } & Control & Treatment & & Control & Treatment \\
\hline Methanol & 0 & 5 & & 33 & 25 \\
Dichloromethane & 0 & 2 & & 33 & 24 \\
Tween-20 pure & 0 & 38 & & 17 & 100 \\
Tween-20 1\% & 14 & 23 & & 20 & 24 \\
Tween-20 5\% & 14 & 22 & & 20 & 38 \\
Dimethyl sulphoxide pure & 3 & 100 & & 11 & 100 \\
Dimethyl sulphoxide 1\% & 2 & 2 & & 1 & 1 \\
Dimethyl sulphoxide 5\% & 1 & 1 & & 1 & 1 \\
\hline
\end{tabular}

Analysing the results using ANOVA, the first analysis was confirmed. Differences were found between concentrations due to the exposure way. Thus DMSO pure had a significant effect ( $p=0.000126)$ in both way, however, Tween-20 showed differences only in the ingestion experiments $(p=0.000126)$, with no significant contact ( $p=0.772315$ ), in other words, the effect using Tween-20 is smaller by contact than ingestion (Table 4).

The results suggest that the solvents: DMSO (1 and $5 \%$ ), Tween-20 (1 and 5\%), DCM and $\mathrm{MeOH}$ (both pure) can be used as solubilizant agents in future organic plant extracts bioassays to evaluate their toxicity effect on adults of the $S$. zeamais. The results also suggest that they will not probably interfere on result, for not causing negatives effects on the target.

\section{DISCUSSION}

In assays that look for plant extracts insecticidal activity should not be observed deleterious effect of the solubilizant agent on the organism target. However, it is often impossible to know in advance if the solvent chosen as solubilizant has toxic effect on individuals or not. So, it is essential to evaluate the solvents before perform toxicological assays with extracts. In agreement with our results some researchers working with organic extracts didn't observe negative effects caused by the solvents on the organism target.

Souza et al. (2007) studying methanolic and ethanolic extracts of Annona coriaceous Mart. in nymphs of Dichelops melacanthus Dallas, 1851 (Heteroptera: Pentatomidae), dissolved in DMSO (40\%) and hexanic extracts dissolved in Tween (1:1) did not observe any negative effect of the solvents on these individuals. Prophiro et al. (2008) studying Melia azedarach L. green and ripe fruits crude extracts, dissolved in Tween-20 against Aedes aegypti Linnaeus, 1762 (Diptera: Culicidae), observed the larvae mortality inexistence in all of the control groups, as well as observed by Montenegro et al. (2006) in contact assay when extracts were dissolved in DMSO 1\% aqueous solution.

Fonseca et al. (2006) evaluating antimicrobial activity of the fruit essential oil from Vitex cymosa Bert. used $10 \mu \mathrm{L}$ of each oil diluted in Tween-80 (0.5\%) were not mention any negative solvent effects. Kannathasan et al. (2008) testing larvicidal activity of fatty acid methyl esters of Vitex species against Culex quinquefasciatus Say, 1823 (Diptera: Culicidae) did not found any toxicity using DMSO at $5 \%$. Similar result was found by Roel et al. (2000) and Cunha et al. (2006) who used acetone as a solvent and they did not found deleterious

Table 4 - Summary of ANOVA three-way analyses considering the solvents dimethyl sulphoxide (DMSO) and Tween-20, concentrations and administration way on Sitophilus zeamais individuals.

\begin{tabular}{lrcrcc}
\hline \multicolumn{1}{c}{ Effect / factor } & d.f. & MS & F & $p$ \\
\hline Solvent & 1 & 14.016666 & 2.1731267 & 0.14697 \\
Concentration & 2 & 1261.6666 & 195.60724 & $<0.00001^{*}$ \\
Administration way $(\mathrm{AW})$ & 1 & 150.41667 & 23.320414 & $<0.00001^{*}$ \\
Solvent $\times$ Concentration $\times$ AW & 2 & 70.199997 & 10.883721 & $0.00012^{*}$ \\
Residual & 48 & 6.4499998 & & \\
\hline
\end{tabular}

* Significance levels $(p<0.05)$. 
effect on control group, as well as Trindade et al. (2000) who used methanol as solubilizant agent.

In view of the importance of knowing how toxic the solvent used as solubilizant agent can be Sarti et al. (1996) when seeking trypanosome activity in plant extracts, determined in advance how much ethanol could be used to dilute the extracts to achieve a concentration that does not kill the parasites and they found that $10-30 \mu \mathrm{L} \cdot \mathrm{mL}^{-1}$ of ethanol in blood were no toxic. Hoold et al. (2003) studying Tween-80 realized that this surfactant provoked an increase in the membrane cellular permeability of the individuals studied, increasing their susceptibility. In addition, Santos et al. (2003) studying the effect of the Tween-80 (1\%) on lettuce plantules, demonstrated that this surfactant affect the growth of plantules radicle and hypocotyl.

Prophiro et al. (2008) did not found negative effect when using Tween-20 pure over $A$. aegypti. As our results show toxic effect of Tween-20 pure over $S$. zeamais, these corroborates the importance of knowing how much toxic one solvent can be for each group studied. It is important to note that the susceptibility of individuals can be very variable among different species, or between individuals of the same species and also the variability of answers can be dependent on the solvent composition.

In summary, the solvents DMSO and Tween-20 can be used diluted at 1 or $5 \%$, while $\mathrm{DCM}$ and $\mathrm{MeOH}$ can be used pure to perform the assays of plant extracts on adults of S. zeamais.

Acknowledgements - We thank the Programa de Pesquisa em Biodiversidade (PPBio/INPA/MCT) and the Conselho Nacional de Desenvolvimento Científico e Tecnológico (CT-Agro/CNPq and $\mathrm{PPBio} / \mathrm{CNPq}$ ) for the financial support.

\section{REFERENCES}

ALMEIDA, S. A., ALMEIDA, F. A. C., SANTOS, N. R., ARAÚJO, M. E. R. \& RODRIGUES, J. P., 2004, Atividade inseticida de extratos vegetais sobre Callosobruchus maculatus (Fabr., 1775) (Coleoptera: Bruchidae). Rev. Bras. Agroc., 10:67-70.

AMARAL, F. M. M., RIBEIRO, M. N. S., BARBOSA-FILHO, J. M., REIS, A. S., NASCIMENTO, F. R. F. \& MACEDO, R. O., 2006, Plants and chemical constituents with giardicidal activity. Rev. Bras. Farmacog., 16:696-720. doi: 10.1590/S0102$695 X 2006000500017$.

CHAGAS, A. C. S., PASSOS, W. M., PRATES, H. T., LEITE, R. C., FURLONG, J. \& FORTES, I. C. P., 2002, Acaricide effect of Eucalyptus spp. essential oils and concentrated emulsion on Boophilus microplus. Braz. J. Vet. Res. Anim. Sci., 39:247-253.

COITINHO, R. L. B. C., OLIVEIRA, J. V., GONDIM JUNIOR, M. G. C. \& CÂMARA, C. A. G., 2006, Efeito residual de inseticidas naturais no controle de Sitophilus zeamais Mots. em milho armazenado. Rev. Caatinga, 19:183-191.

CUNHA, U. S., VENDRAMIM, J. D., ROCHA, W. C. \& VIEIRA, P. C., 2006, Frações de Trichilia pallens com atividade inseticida sobre Tuta absoluta. Pesq. Agropec. Bras., 41:1579-1585. doi: 10.1590/S0100-204X2006001100002.

ESTRELA, J. L. V., FAZOLIN, M., CATANI, V., ALÉCIO, M. R. \& LIMA, M. S., 2006, Toxicity of essential oils of Piper aduncum and Piper hispidinervum against Sitophilus zeamais. Pesq. Agrop. Bras., 41:217-222. doi: 10.1590/S0100-204X2006000200005.

FAZOLIN, M., ESTRELA, J. L. V., CATANI, V., ALÉCIO, M. R. \& LIMA, M. S., 2007, Insecticide activity of the essencial oil Tanaecium nocturnum (Barb. Rodr.) Bur. \& K. Shum (Bignoneaceae) on Sitophilus zeamais Motsch. (Coleoptera: Curculionidae). Acta Amaz., 37:599-604.

FAZOLIN, M., ESTRELA, J. L. V., LIMA, A. P. \& ARGOLO, V. M., 2002, Avaliação de plantas com potencial inseticida no controle da vaquinha-do-feijoeiro (Cerotoma tingomarianus Bechyné). Pesq. Agrop. Bras., Bol. Pesq. Desenvol., 37:5-34.

FONSECA, E. N., FIGER, A., FURTADO, D. T., LOPES, D., ALVIANO, C. S. \& LEITAO, S. G., 2006, Análise química e atividade antimicrobiana do óleo essencial dos frutos de Vitex cymosa Bertero. Rev. Bras. Pl. Med., 8:87-91.

GALLO, D., NAKANO, O., SILVEIRA NETO, S., CARVALHO, R. P. L., BATISTA, G. C., BERTI FILHO, E., PARRA, J. R. P., ZUCCHI, R. A., ALVES, S. B., VENDRAMIM, J. D., MARCHINI, L. C., LOPES, J. R. S. \& OMOTO, C., 2002, Entomologia agrícola, 3. ed., FEALQ, São Paulo, Brasil, 920p.

GONÇALVES-GERVÁSIO, R. C. R. \& VENDRAMIM, J. D., 2004, Efeito de extratos de meliáceas sobre o parasitóide de ovos Trichogramma pretiosum Riley (Hymenoptera: Trichogrammatidae). Neotrop. Entomol., 33:607-612. doi: 10.1590/S1519-566X2004000500010.

HAMMER, K. A., CARSON, C. F. \& RILEY, T. V., 1999, Antimicrobial activity of essential oils and others plants extracts. J. Appl. Microb., 86:985-990. doi: 10.1046/j.13652672.1999.00780.

HOOLD, J. R., WILKINSON, J. M. \& CAVANAGH, H. M. A., 2003, Evaluation of common antibacterial screening methods utilized in essential oil research. J. Essent. Oil Res., 15:428-433.

INOUE, Y., HADA, T., SHIRAISHI, A., HIROSE, K., HAMASHIMA, H. \& KOBAYASHI, S., 2005, Biphasic effects of geranylgeraniol, teprenone, and phytol on the grouth of Staphylococcus aureus. Antimicrob. Agents Chemother., 49:17701774. doi: 10.1128/AAC.49.5.

JACOBSON, M., 1982, Plants, Insects and Man - Their interrelationships. Econ. Bot., 36:346-352.

KANNATHASAN, K., SENTHILKUMAR, A., VENKATESALU, V. \& CHANDRASEKARAN, M., 2008, Larvicidal activity of fatty acid methyl esters of Vitex species against Culex quinquefasciatus. Parasitol. Res., 103:999-1001. doi: 10.1007/ s00436-008-1078-1.

KUKIĆ, J., POPOVIĆ, V., PETROVIĆ, S., MUCAJ, P., ĆIRIĆ, A., STOJKOVIĆ, D. \& SOKOVIĆ, M., 2008, Antioxidant and antimicrobial activity of Cynara cardunculus extracts. Food Chem., 107:861-868. doi: 10.1016/j.foodchem.2007.09.005.

LAZZARI, S. M. N. \& LAZZARI, F. A., 2009, Insetos-praga de grãos armazenados. In: A. R. Panizzi \& J. R. P. Parra (ed.), Bioecologia e nutrição de insetos: base para o manejo integrado de pragas. Embrapa Informação Tecnológica, Brasília, DF, p.667-731.

LEE, B. H., ANNIS, P. C., TUMAALII, F. \& CHOI, W. S., 2004, Fumigant toxicity of essential oils from the Myrtaceae family and 1,8-cineole against 3 major stored-grain insects. J. Stored Prod. Res., 40:553-564. doi: 10.1016/j.jspr.2003.09.001.

LIU, L. Z. \& HO, S. H., 1999, Bioactivity of the essential oil extracted from Evodia rutaecarpa Hook f. Thomas against the grain storage insects, Sitophilus zeamais (Motsch.) and Tribolium castaneum (Herbst). J. Stored Prod. Res., 35:317-328. doi: 10.1016/S0022-474X(99)00015-6. 
LLANOS, C. A. H., ARANGO, D. L. \& GIRALDO, M. C., 2008, Insecticidal activity of Annona muricata (Annonaceae) seed extracts on Sitophilus zeamais (Coleoptera: Curculionidae). Rev. Colombiana Entomol., 34:76-82.

MAHASNEH, A. M. \& El-OQLAH, A. A., 1999, Antimicrobial activity of extracts of herbal plants used in the traditional medicine of jordan. J. Ethnopharmacol., 64:271-276. doi: 10.3923/jbs.2006.109.114.

MONTENEGRO, L. H. M., OLIVEIRA, P. E. S., CONSERVA, L. M., ROCHA, E. M. M., BRITO, A. C., ARAÚJO, R. M., TREVISAN, M. T. \& LEMOS, R. P. L., 2006, Terpenoids and Evaluation of the Antimalarial, Larvicidal, Anti-radicalar and Anticholinesterase Potential of Pouteria venosa (Sapotaceae). Rev. Bras. Farmacog., 16:611-617. doi: 10.1590/S0102695X2008000500010.

NASCIMENTO, F. R., CARDOSO, M. G., SOUZA, P. E., LIMA, R. K., SALGADO, A. P. S. P. \& GUIMARÃES, L. G. L., 2008, The effect of Long-pepper essential oil (Piper hispidinervum C. DC.) and of Tween ${ }^{\mathbb{8}} 80$ emulsifier on the mycelial growth of Alternaria alternate (Fungi: Hyphomycetes). Acta Amaz., 38:503-508.

OLIVEIRA, J. V. \& VENDRAMIM, J. D., 1999, Repellency of essential oils and powders from plants on adults of Zabrotes subfasciatus (Boh.) (Coleoptera: Bruchidae) on bean seeds. An. Soc. Entomol. Bra., 28:549-555. doi: 10.1590/S030180591999000300026.

PAPACHRISTOS, D. P. \& STAMOPOULOS, D. C., 2004, Fumigant toxicity of three essential oils on the eggs of Acanthoscelides obtectus (Say) (Coleoptera: Bruchidae). J. Stored Prod Res., 40:517-525. doi: 10.1016/j.jspr.2003.07.002.

PAUL, U. V., LOSSINI, J. S., EDWARDS, P. J. \& HILBECK, A., 2009, Effectiveness of products from four locally grown plants for the management of Acanthoscelides obtectus (Say) and Zabrotes subfasciatus (Boheman) (both Coleoptera: Bruchidae) in stored beans under laboratory and farm conditions in Northern Tanzania. J. Stored Prod. Res., 45:97-107. doi: 10.1016/j.jspr.2008.09.006.

POLETTI, M. \& OMOTO, C., 2003, Resistência de inimigos naturais a pesticidas. Exploração de inimigos naturais resistentes a pesticidas em programas de manejo de pragas. Rev. Biotec. Ciência \& Desenv., 30:16-26.

PROCÓPIO, S. O., VENDRAMIM, J. D., RIBEIRO JÚNIOR, J. I. \& SANTOS, J. B., 2003, Bioactivity of powders from some plants on Sitophilus zeamais Mots. (Coleoptera: Curculionidae). Ciênc. Agrotec., 27:1231-1236. doi: 10.1590/S141370542003000600004.

PROPHIRO, J. S., ROSSI, J. C. N., KANIS, L. A., SANTOS, T. G. \& SILVA, O. S., 2008, Comparative study of the larvicidal effect of ripe and unripe fruits extracts of Melia azedarach L. (Sapindales: Meliaceae) on Aedes aegypti L. (Diptera: Culicidae). Bioassay, $3: 2-5$.
ROEL, A. R., VENDRAMIM, J. D., FRIGHETTO, R. T. S. \& FRIGHETTO, N., 2000, Atividade tóxica de extratos orgânicos de Trichilia pallida Swartz (Meliaceae) sobre Spodoptera frugiperda (J. E. Smith). An. Soc. Entomol. Bras., 29:799-808. doi: 10.1590/S0301-80592000000400021.

SAITO, M. L. \& LUCCHINI, F., 1998, Substâncias obtidas de plantas e a procura por praguicidas eficientes e seguros ao meio ambiente. EMBRAPA-CNPMA, Jaguariúna, 46p. ( Série Documentos, 12).

SANTOS, C. C., OLIVEIRA, D. F., ALVES, L. W. R., SOUZA, I. F. \& FURTADO, D. A., 2003, Effect of organic extracts associated with surfactant Tween 80 on seed germination and seedling growth of lettuce. Ciência Agrotéc., 28:296-299. doi: 10.1590/ S1413-70542004000200007.

SARTI, S. J., SILVA, J. S., SANTOS FILHO, D., RIBEIRO DOS SANTOS, R., ROSSI, M. A., BASTOS, J. K., LEITÃO FILHO, H. F., ABREU, J. E., GASPAR, M. E. \& LOPES, W., 1996, Quimioprofilaxia da doença de chagas: Bloqueio da transmissão transfusional por produtos naturais. Rev. Bras. Farmacog., 1:113141. doi: 10.1590/S0102-695X1996000100009.

SOUZA, E. M., CORDEIRO, J. R. \& PEREIRA, M. J. B., 2007, Evaluation of insecticide activity of different extracts of Annona coriacea seeds over Dichelops melacanthus. Rev. Bras. Agroecol., 2:1107-1110.

SOUZA, M. C. C. \& TROVÃO, M. B. M., 2009, Bioactive of extract of plants from dry and nim caatinga (Azadiractha indica) on Sitophilus zeamais Mots. stored in maize. Rev. Verde, 4:120-124.

STAHLMAN, P. W., CURRIE, R. S. \& EL-HAMID, M. A., 1997, Nitrogen carrier and surfactant increase foliar herbicide injury in winter wheat (Triticum aestivum). Weed Technol., 11:7-12.

STATSOFT, Inc., 1997, STATISTICA for Windows [Computer program manual]. StatSoft, Inc., Tulsa, OK. Available from: $<$ http://www.statsoft.com>.

TAPONDJOU, L. A., ADLER, C., BOUDA, H. \& FONTEM, D. A., 2002, Efficacy of powder and essential oil from Chenopodium ambrosioides leaves as post-harvest grain protectants against six-stored product beetles. J. Stored Prod. Res., 38:395-402. doi: 10.1016/S0022-474X(01)00044-3.

TAVARES, M. A. G. C. \& VENDRAMIM, J. D., 2005, Bioactivity of the Mexican-Tea, Chenopodium ambrosioides L., towards Sitophilus zeamais Mots. (Coleoptera: Curculionidae). Neotrop. Entomol., 34:319-323. doi: 10.1590/S1519566X2005000200021.

TRINDADE, R. C. P., MARQUES, I. M. R., XAVIER, H. S. \& OLIVEIRA, J. V., 2000, Neem seed kernel extract and the tomato leafminer egg and larvae mortality. Sci. Agric., 57:407-413. doi: 10.1590/S0103-90162000000300006.

VIEGAS JÚNIOR, C., 2003, Terpenes with insecticide activity: alternative for the insect control. Quim. Nova, 26:390-400. doi: 10.1590/S0100-40422003000300017. 
